\title{
Comparative Quality Evaluation of Different Brands of 'Triphala': A Polyherbal Medicine in Sri Lanka
}

\author{
Ramitha Premathilake ${ }^{1, *}$, Sinnadurai Thuvaragan ${ }^{1}$, Vinotha Sanmugarajah ${ }^{2}$, Ratnasothy Srikaran ${ }^{3}$, Nahmagal Krishnapillai $^{4}$ \\ 'Department of Pharmacy, Faculty of Allied Health Sciences, University of Jaffna, SRI LANKA. \\ 2Unit of Siddha Medicine, University of Jaffna, SRI LANKA. \\ ${ }^{3}$ Department of Chemistry, Faculty of Science, University of Jaffna, SRI LANKA. \\ ${ }^{4}$ Department of Botany, Faculty of Science, University of Jaffna, SRI LANKA.
}

\begin{abstract}
Background: Triphala is a well-known polyherbal formulation widely used as an herbal, complementary and alternative medicine for various ailments, especially for gastrointestinal problems, and it is used as a dietary supplement for long years. Objectives: Objective of this study was to comparatively evaluate the quality of three marketed brands of Triphala tablets (Brand $T_{1}$ and $T_{2}$ ) and capsules (Brand $T_{3}$ ) which are available in Sri Lanka. Materials and Methods: This laboratory based experimental qualitative study was done among three brands of Triphala. Phytochemical screening was carried out for all those brands. Physicochemical tests were also performed to determine $\mathrm{pH}$, moisture content, and loss on ignition, ash values and extractive values. Data were analysed by using Statistical Package of Social Sciences 23. Results: Physicochemical tests revealed that all three brands failed to comply with pharmacopoeial limits at least in one physicochemical test. According to ANOVA test, there was significant difference between
\end{abstract}

results of physicochemical tests of marketed brands of Triphala. Conclusion: All three Triphala brands did not meet the quality standards. Quality of herbal medicine marketed in Sri Lanka should be monitored and regularized by relevant authorities.

Key words: Marketed Brands, Physicochemical Tests, Phytochemical Screening, Quality, Sri Lanka, Triphala.

Correspondence

Mr. Sinnadurai Thuvaragan,

Department of Pharmacy, Faculty of Allied Health Sciences, University of Jaffna, SRI LANKA.

Email id: sthuvaragan@univ.jfn.ac.lk

DOI: 10.5530/jyp.2021.13.48

\section{INTRODUCTION}

The World Health Organization has been estimated that $80 \%$ of the population in developing countries depends on traditional herbal medicines. The herbal products are widely used as a complementary and alternative medicine for different ailments, ${ }^{1-3}$ and also people use those as dietary supplements ${ }^{4,5}$ in Sri Lanka.

Triphala is a poly-herbal medicine, which consists of dried fruits of three medicinal plants which are Terminalia chebula Retz (Family Combretaceae), Terminalia bellerica Roxb (Family Combretaceae) and Phyllanthus emblica L. (Family Phyllanthaceae) in equal proportions, based on Ayurvedic Formulary of India (AFI). Commonly, Triphala is used for treating a variety of ailments, especially for gastrointestinal problems $s^{6,7}$ and used for prevention of dental caries ${ }^{8-10}$ and cardio-cerebral vascular diseases. ${ }^{11} \mathrm{~A}$ randomized controlled trial which was done to test the effects of Triphala formulation, on serum lipid parameters in patients receiving atorvastatin at Sri Lanka stated that the use of that Triphala as single therapy for lipid regulation. ${ }^{12}$

Based on scientific studies related to the Triphala, it possesses antiinflammatory, ${ }^{13,14}$ anti-microbial, ${ }^{15}$ anti-arthritic, ${ }^{14,16}$ antioxidant, ${ }^{17}$ analgesic, rejuvenating (anti-ageing), ${ }^{1,8,18}$ hypoglycaemic ${ }^{19}$ and anticancer properties. ${ }^{20,21}$ It also possesses chemo-protective, immune-modulating, anti-mutagenic, adaptogenic, and radio-protective effects. ${ }^{8-10}$

Pharmacognostic techniques used in the standardization of plant material include morphological features, physicochemical characteristics, fluorescence analysis and preliminary phytochemical analysis. ${ }^{18,22}$ These standards are of utmost importance in finding out genuinely and in the detection of adulterants in marketed drug. ${ }^{23}$
Nowadays, most of the herbal medicines are produced as tablets or capsules. Triphala is well known poly herbal medicine, and it is used in the treatment of different ailments in Sri Lanka. Therefore, this study was done to comparatively evaluate the mostly available three Triphala brands in the form of tablets and capsules in Sri Lanka.

\section{MATERIALS AND METHODS}

The study was limited to tablets and capsules of Triphala. Three mostly available brands of Triphala tablets $\left(\mathrm{T}_{1}\right.$ and $\left.\mathrm{T}_{2}\right)$ and capsules $\left(\mathrm{T}_{3}\right)$ in Sri Lanka were included in this study. Description of these three brands were given in Table 1. Powder sample that were obtained from these brands, was used for preliminary phytochemical screening and physicochemical analysis. All tests were carried out for the three brands within their expiry date.

\section{Preliminary phytochemical screening}

Preliminary phytochemical screening of aqueous extracts of each brand of Triphala powder was performed to detect various bioactive substances such as alkaloids, carbohydrates, reducing sugar, flavonoids, saponins, tannins, steroids, proteins, amino acids, glycosides, phenols, terpenoids and ascorbic acid. ${ }^{3,24}$

\section{Physicochemical analysis}

Each test was done according to standard methods prescribed in World Health Organization guidelines for quality control methods for herbal materials, Association of Official Agricultural Chemists International methods and Indian Pharmacopeia and the Ayurvedic Pharmacopeia. ${ }^{25-27}$ 
Table 1: Details of Triphala products.

\begin{tabular}{ccccc}
\hline Code & $\begin{array}{c}\text { Manufacturing } \\
\text { date }\end{array}$ & Expiry date & Batch number & $\begin{array}{c}\text { Dosage } \\
\text { form }\end{array}$ \\
\hline $\mathrm{T}_{1}$ & $01 / 07 / 2020$ & $01 / 07 / 2021$ & 031054 & Tablet \\
$\mathrm{T}_{2}$ & $29 / 01 / 2020$ & $28 / 01 / 2022$ & $\mathrm{~B} 107$ & Tablet \\
$\mathrm{T}_{3}$ & $03 / 12 / 2019$ & $02 / 12 / 2021$ & $698 \mathrm{~A}$ & Capsule \\
\hline
\end{tabular}

Table 2: Phytochemical screening of Different Brands of Triphala.

\begin{tabular}{ccccc}
\hline Phytochemicals & Test & $\mathrm{T}_{1}$ & $\mathrm{~T}_{2}$ & $\mathrm{~T}_{3}$ \\
\hline Alkaloids & Mayer's test & - & - & - \\
& Wagner's test & - & - & - \\
Carbohydrates & Molisch's test & + & + & + \\
Reducing sugar & Fehling's test & + & + & + \\
Flavonoids & Alkaline reagent test & + & + & + \\
& Lead acetate test & + & + & + \\
Saponins & Foam test & + & + & + \\
Tannins & Braymer's test & + & + & + \\
Steroids & Salkowski's test & + & + & + \\
Proteins & Millon's test & - & - & - \\
Amino acids & Ninhydrin test & - & - & - \\
Glycosides & Keller Killiani's test & + & + & - \\
Phenols & FeCl test & + & + & + \\
& Lead acetate test & + & + & + \\
Terpenoids & Copper acetate test & - & - & - \\
Ascorbic acid & Vitamin C test & + & + & + \\
\hline
\end{tabular}

+ Present; - Absent

Physicochemical tests such as determination of $\mathrm{pH}$ value, ${ }^{3}$ moisture content (Loss on Drying), Loss on Ignition, ${ }^{28}$ ash values (Total ash, Acidinsoluble ash, Water-soluble ash) and extractive values (Ethanol-soluble and Water-soluble extractive value) were done in triplicate for each brands.

\section{Statistical analysis}

Statistical analysis was performed using the statistical package of social science (SPSS) 23 and results were presented as mean values and standard deviations. One-way ANOVA (analysis of variance) test was used to compare results of physicochemical tests of different brands. $P$ value less than 0.05 will be considered as statistically significance difference.

\section{RESULTS}

In this qualitative experimental study, the three different marketed brands were comparatively evaluated using physicochemical and phytochemical analysis.

\section{Phytochemical screening}

Based on the Table 2, Phytochemical screening of aqueous extracts revealed that carbohydrates, reducing sugar, flavonoids, saponins, tannins, steroids, phenols and ascorbic acid were present in all the brands while glycosides was present only in $\mathrm{T}_{1}$ and $\mathrm{T}_{2}$. Alkaloids, proteins, amino acids and terpenoids were absent in all brands.

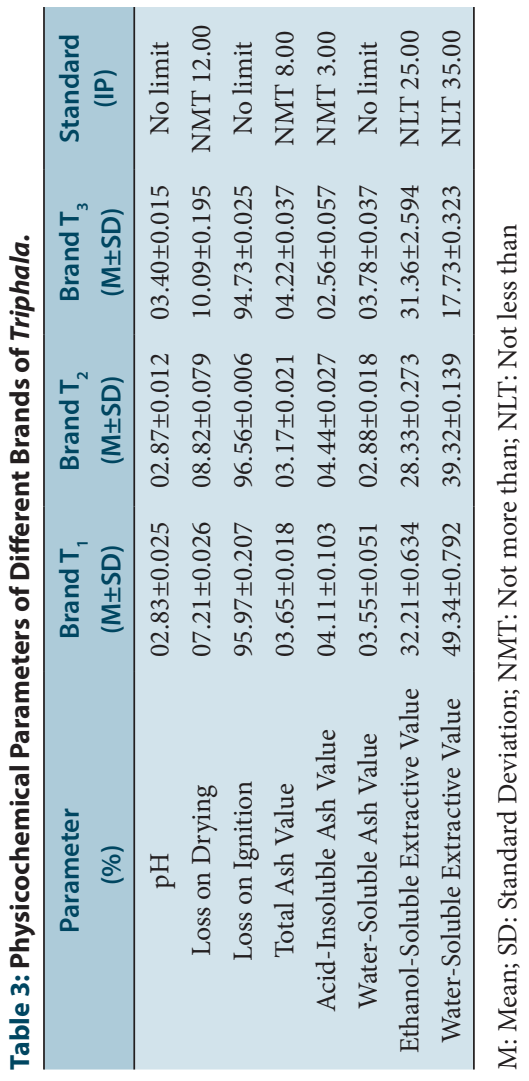

\section{Physicochemical analysis}

According to the Table 3, Brand $\mathrm{T}_{3}$ had higher values in $\mathrm{pH}$, loss on drying, total ash and water-soluble ash values than other two $\left(\mathrm{T}_{1}\right.$ and $\left.\mathrm{T}_{2}\right)$ brands Brand $\mathrm{T}_{2}$ had higher loss on ignition and Acid-insoluble ash values, while $\mathrm{T}_{1}$ had higher ethanol-soluble and water-soluble extractive values. All physicochemical parameters except acid-insoluble ash value in $\mathrm{T}_{1}$ and $\mathrm{T}_{2}$ and water-soluble extractive value in $\mathrm{T}_{3}$ were complied with the Standard limits mentioned in Indian Pharmacopoeia. The mean comparison of all three brands by using one-way Analysis of variance (ANOVA) statistical test showed significant difference in physicochemical parameters of all tested brands $(<0.05)$ except in ethanol-soluble extractive value in which no significant difference (Between $\mathrm{T}_{1}$ and $\mathrm{T}_{3}$ and $\mathrm{T}_{2}$ and $\mathrm{T}_{3}$ ) was observed (>0.05).

\section{DISCUSSION}

Quality of three brands of Triphala was evaluated using phytochemical screening and physicochemical tests.

Several studies on preliminary phytochemical screening revealed that the aqueous and alcohol extracts of Triphala powder consisted of phenolics, tannins, ascorbic acid, flavonoids, sugar, starch and fixed oil. ${ }^{18}$ 21-23 Generally, polyphenols, tannins, ascorbic acid, flavonoids, sugar and starch are major phytoconstituents in Triphala.,29-32 In this study, phytochemical screening of aqueous extract confirmed the presence of carbohydrates, reducing sugar, flavonoids, saponins, tannins, steroids, phenols and ascorbic acid in all three brands while glycosides were present only in brands $\mathrm{T}_{1}$ and $\mathrm{T}_{2}$. Alkaloids, proteins, amino acids and terpenoids were absent in all three brands. In the previous study on Triphala churna, the phytochemical screening of the aqueous extract of different brands revealed the presence of carbohydrates, steroids, flavonoids, tannins, saponins, phenols and ascorbic acid while glycosides only 
in one brand with the absence of alkaloids, proteins, amino acids and terpenoids. ${ }^{3}$ However, another study done for a marketed brand and a lab-prepared sample confirmed the presence of alkaloids and the absence of saponins and proteins. ${ }^{30}$ Another study confirmed the absence of glycosides, proteins, saponins, alkaloids and phytosterols. ${ }^{29}$ Current and previous studies showed variations in the phytochemical constituents. Since phytochemical screening is a qualitative study, it may not detect some phytoconstituents which was in the low quantity in the samples.

The African Pharmacopeia stated that physicochemical evaluation of drugs is an essential parameter in detecting adulteration or improper handling of drugs. ${ }^{33}$ In this study, the $\mathrm{pH}$ of the all Triphala brands was in the range of 2.83 to 3.40. Presence of ascorbic acid may contribute to the low $\mathrm{pH}$ of the Triphala formulations. Previous study done with different brands of Triphala churna in India also showed comparable $\mathrm{pH}$ values ${ }^{3}$ while a study reported different $\mathrm{pH}$ value. ${ }^{34}$ Loss on drying was used to determine the volatile constituents in powdered drugs. Low moisture content is often desirable for stability of herbal drugs. Low moisture content of drugs could prevent microbial growth during storage. ${ }^{35-37}$ In this study, all three brands were within the limit $(\geq 12 \% \mathrm{w} / \mathrm{w})$ in loss on drying values. However, $\mathrm{T}_{3}$ had high value of loss on drying compare to others. Even though loss on ignition is one of the most widely used methods for determining the content of organic matter in herbs, it was not included as standard tests. In this study, the loss on ignition values of $\mathrm{T}_{1}, \mathrm{~T}_{2}$ and $\mathrm{T}_{3}$ were comparable with the previous study done in India. ${ }^{3}$ Ash values were used to determine the quality and purity of the unsophisticated drug. ${ }^{35}$ Low ash values indicate more purity and quality. High ash values may be due to contamination, substitution, adulteration or carelessness in preparing the herbal formulations. Acid-insoluble ash value indicates presence of siliceous impurities. Water-soluble ash value is due to presence of inorganic contents. In this study, ash values were within the standard limit $(\geq 8 \%)$. These values were comparable with the findings of previous studies. ${ }^{3,30}$ Acid insoluble ash values of 03 brands were in the range from 2.56 to $4.44 \% \mathrm{w} / \mathrm{w}$. The acid insoluble ash value of $\mathrm{T}_{3}$ was within the standard limit (IP limit of $\geq 3.0 \%$ ) while $\mathrm{T}_{1}$ and $\mathrm{T}_{2}$ were exceed the limit. The acid-insoluble ash value of the $\mathrm{T}_{3}$ was comparable with the previous study. ${ }^{3}$ High acid-insoluble ash value was observed in two brands in this study, and it might be due to the presence of more earthy materials. The water-soluble ash values of the Triphala brands ranged from 2.88 to $3.78 \% \mathrm{w} / \mathrm{w}$. But these values were not comparable with water-soluble ash values of previous studies. ${ }^{3,21,22}$

The extractive values (alcohol and aqueous) are useful to estimate the soluble chemical constituents in the crude drug. ${ }^{36}$ Low Ethanol soluble extractive values indicate usage of exhausted material, adulteration, using less amount of herbals, incorrect processing or storage. In this study, the values of all three brands were within the IP limit $(\leq 25.0 \%)$ and could be comparable with the previous study. ${ }^{3}$ Water-soluble extractive value of $\mathrm{T}_{3}$ was within standard limit. But $\mathrm{T}_{1}$ and $\mathrm{T}_{2}$ were exceed the limit $(\geq 35.0 \%)$ and same results was reported in the previous studies. ${ }^{3,29,30,34}$ In the present study, water-soluble extractive value was higher than alcohol extractives. It could be due to that most of the phytoconstituents in the sample were solubilised in water. Additions of exhausted material, adulteration or incorrect processing might contribute to less water extractive values. In this study, all three brands failed to satisfy the standard limit in at least one physicochemical test. ANOVA test also revealed that statistically significant differences $(<0.05)$ in all physicochemical tests except in ethanol soluble extractive value.

Difference in the results of phytochemical screening is due to several reasons such as preparation procedure, storage method, seasonal variations, and collection of plant materials from different phytogeographical regions, variation in quantity of each plant, adulteration or substitution. Since different excipients are added for ease of production of tablets and capsules, they may have an impact on quality control tests such as physicochemical tests and phytochemical screening. Currently, many herbal formulations are processed in to capsules and tablets. So that existing standard limits should be revised for herbal based tablets and capsules.

\section{CONCLUSION}

There was a significant difference in the most physicochemical tests among all three marketed Triphala brands. All three brands failed to comply with standard limit in at least one physicochemical test. Herbal based drugs should be monitored for their quality by relevant authorities. Further, standard limits used for assessing the quality of herbal base capsules and tablets should be revised.

\section{ACKNOWLEDGEMENT}

The authors acknowledge University of Jaffna to support this study.

\section{CONFLICT OF INTEREST}

The authors declare that there is no conflict of interest.

\section{ABBREVIATIONS}

AFI: Ayurvedic Formulary of India; WHO: World Health Organization; SPSS: Statistical Package of Social Science; ANOVA: Analysis of Variance; M: Mean; SD: Standard Deviation; NMT: Not more than; NLT: Not less than.

\section{REFERENCES}

1. Biradar YS, Sharma P, Khandelwal KR. Preparation, optimization and physicochemical evaluation of traditional formulation. Triphala Mashi. Indian J Tradit Know. 2007;6(2):292-7.

2. Sharma S, Gupta M, Bhadauria R. Phytochemical Variations in Commercially Available Triphala Powder: A Well Known Dietary Supplement of Indian System of Medicine. Res J Med Plants. 2014;8(5):214-22. doi: 10.3923/ rjmp.2014.214.222.

3. Agarwal P, Goyal A, Vaishnav R. Comparative Quality Assessment of three Different Marketed Brands of Indian Poly herbal Formulation-Triphala Churna. Biomed J Sci Tech Res. 2018;5(4):4686-94

4. Perera PK. Current scenario of herbal medicine in Sri Lanka. Proceeding of the 4th Annual Herbal International Summit cum Exhibition on Medicinal \& aromatic Products, Spices and finished products (hi-MAPS). Okhla Industrial Estate, New Delhi, India: NSIC; 2012 Apr 14-15. ASSOCHAM; 2012: 28-31.

5. Wijesinghe W, Pilapitiya S, Hettiarchchi P, Wijerathne B, Siribaddana S. Regulation of herbal medicine use based on speculation? A case from Sri Lanka. J Tradit Complement Med. 2017;7(2):269-71. doi: 10.1016/j.jtcme.2016.06.009, PMID 28417096.

6. Baliga MS. Triphala, Ayurvedic formulation for treating and preventing cancer: a review. J Altern Complement Med. 2010;16(12):1301-8. doi: 10.1089/ acm.2009.0633, PMID 21138390

7. Baliga MS, Meera S, Mathai B, Rai MP, Pawar V, Palatty PL. Scientific validation of the ethnomedicinal properties of the Ayurvedic drug Triphala: a review. Chin J Integr Med. 2012;18(12):946-54. doi: 10.1007/s11655-012-1299-x, PMID 23239004.

8. Mukherjee PK, Rai S, Bhattacharyya S, Kumar DP, Biswas TK, Jana U, et al. Clinical study of Triphala-a well-known phytomedicine from India. Iran J PharmacolTher 2006;5(1):51-60

9. Peterson CT, Denniston K, Chopra D. Therapeutic uses of Triphala in ayurvedic medicine. J Altern Complement Med. 2017;23(8):607-14. doi: 10.1089/ acm.2017.0083, PMID 28696777.

10. Shanbhag VK. Triphala in prevention of dental caries and as an antimicrobial in oral cavity- a review. Infect Disord Drug Targets. 2015;15(2):89-97. doi: 10.2174/1 871526515666150513105009, PMID 25966965.

11. Wang W, Liu T, Yang L, Ma Y, Dou F, Shi L, Wen A, Ding Y. Study on the multitargets mechanism of Triphala on cardio-cerebral vascular diseases based on network pharmacology. Biomed Pharmacother. 2019;116:108-9. doi: 10.1016/j. biopha.2019.108994.

12. Ekanayaka RAI, Rupasinha ADCS, Sooriyarachchi MR, Goonaratna C. The effect of thriphala, a herbal Ayurveda formulation, on serum lipids, in patients on a maintenance dose of atorvastatin for hyperlipidaemia: a randomized controlled trial. Ceylon Med J. 2017;62(3):128-40. doi: 10.4038/cmj.v62i3.8516, PMID 29072054. 
13. Sireeratawong S, Jaijoy K, Soonthornchareonnon N. Evaluation of anti-inflammatory and antinociceptive activity of Triphala recipe. Afr J Tradit Complement Altern Med. 2013;10(2):246-50. doi: 10.4314/ajtcam.v10i2.8, PMID 24146447.

14. Kalaiselvan S, Rasool MK. The anti-inflammatory effect of Triphala in arthriticinduced rats. Pharm Biol. 2015;53(1):51-60. doi: 10.3109/13880209.2014.910237, PMID 25289531.

15. Saxena S. Anti Bacterial Efficacy of Terminalia Chebula, Terminalia Bellirica, Embilica Officinalis and Triphala on Salivary Streptococcus Mutans Count - A Linear Randomized Cross Over Trial. J Clin Diagn Res. 2017;11(2):47-51. doi: 10.7860/JCDR/2017/23558.9355.

16. Rasool M, Sabina EP. Antiinflammatory effect of the Indian Ayurvedic herbal formulation Triphala on adjuvant-induced arthritis in mice. Phytother Res. 2007;21(9):889-94. doi: 10.1002/ptr.2183, PMID 17533629.

17. Hazra B, Sarkar R, Biswas S, Mandal N. Comparative study of the antioxidant and reactive oxygen species scavenging properties in the extracts of the fruits of Terminalia chebula, Terminalia belerica and Emblica officinalis. BMC Complement Altern Med. 2010;10(1):20. doi: 10.1186/1472-6882-10-20, PMID 20462461.

18. Parveen R, Shamsi TN, Singh G, Athar T, Fatima S. Phytochemical analysis and in vitro Biochemical Characterization of aqueous and methanolic extract of Triphala, a conventional herbal remedy. Biotechnol Rep (Amst). 2018;17:126-36. doi: 10.1016/j.btre.2018.02.003, PMID 29619331.

19. Rajan SS, Antony S. Hypoglycemic effect of triphala on selected non insulin dependent Diabetes mellitus subjects. Anc Sci Life. 2008;27(3):45-9. PMID 22557278.

20. Tsering J, Hu X. Triphala suppresses growth and migration of human gastric carcinoma cells in vitro and in a zebrafish xenograft model. BioMed Res Int. 2018;2018:7046927. doi: 10.1155/2018/7046927, PMID 30643816.

21. Wang M, Li Y, Hu X. Chebulinic acid derived from Triphala is a promising antitumour agent in human colorectal carcinoma cell lines. BMC Complement Altern Med. 2018;18(1):342. doi: 10.1186/s12906-018-2412-5, PMID 30587184.

22. Yadav P, Mahour K, Kumar A. Standardization and Evaluation of Herbal Drug formulations. J Adv Lab Res Biol. 2011;II(IV):192-9.

23. Arunkumar S, Muthuselvam M. Analysis of phytochemical constituents and antimicrobial activities of Aloe vera L. against clinical pathogens. World J Agric Sci. 2009;5(5):572-6

24. Naik GH, Priyadarsini KI, Mohan H. Free radical scavenging reactions and phytochemical analysis of triphala, an ayurvedic formulation. Curr Sci. 2006;90(8):1100-5.

25. Rev. Organization mondiale de la Sante. [Quality control methods for plant materials]. World Health Organization; 1998; 559. p. 8-67.

26. Ministry of Health and Family Welfare, Government of India. New Delhi. The Ayurvedic Pharmacopoeia India. Part I First Edit. 2008;VI:1-492.

27. Pharmacopoeia Commission for Indian Medicine \& Homoeopathy. The ayurvedic pharmacopoeia of India. Part I. First edit. Vol. IX. Ghaziabad: PLIM Campus. Government of India, Ministry of AYUSH; 2016. p. 1-182.

28. Heiri O, Lotter AF, Lemcke G. Loss on ignition as a method for estimating organic and carbonate content in sediments: reproducibility and comparability of results. J Paleolimnol. 2001;25(1):101-10. doi: 10.1023/A:1008119611481.

29. Ashokkumar D. Pharmacognostical investigations on Triphala churnam. Anc Sci Life. 2007;26(3):40-4. PMID 22557240.

30. Venkateswarlu G, Ganapaty S, Sudhakar AMS. Preparation of Triphala Churna using the ingredients obtained from local market and comparative standardization. Pharmacol J. 2019;11(1):102-11. doi: 10.5530/pj.2019.1.18.

31. Mukherjee P, Rai S, Bhattacharyya S, Wahile A, Saha B. Marker analysis of polyherbal formulation, Triphala - A well-known Indian traditional medicine. Indian J Tradit Know. 2008;7:379-83.

32. Kondawar MS, Kamble KG, Mali DS. Quantitative estimation of gallic acid and ascorbic acid in a marketed herbal medicine. Triphala Churna by high performance thin layer chromatography. Int. J Pharm Tech Res. 2011;3:1593-9.

33. Kala S, Johnson M, Janakiraman N, Anto AA, Iyan RS, Bosco D. Pharmacognostic and phytochemical studies on some selected ethnomedicinal plants of Tamil nadu, South India. Int J Arom Plants. 2011;1(2):89-94.

34. Rajan K, Praveen K, Vaibhav R, Gauranga SR. Physicochemical evaluation of Triphala churna. Int J Pharm Sci. 2015;1(1):71-4.

35. Swamy P, Kamil MS. Preliminary pharmacognostical and phytochemical evaluation of Portulaca quadrifida Linn. Int J PharmTech Res. 2010;2(3):1699-702.

36. Sushil S, Madhu G, Rekha B. Mycobiota of commercially available Triphala powder: A well known dietary supplement of Indian system of medicine. J Mycol. 2014:1-8.

37. Danladi A, Helen II, Sabo EY, Olayeni SO. Contamination of Herbal products marketed in Kaduna Metropolis with selected Pathogenic Bacteria. Afr J Tradit Complement Altern Med. 2009;6(1):70-7.

Article History: Received: 28-04-2021;Revised: 21-05-2021;Accepted: 15-06-2021

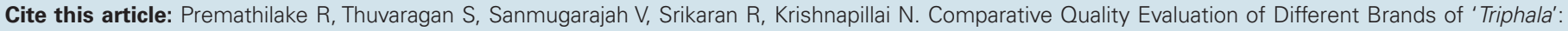
A Polyherbal Medicine in Sri Lanka. J Young Pharm. 2021;13(3):235-8. 